\title{
Analysis on Health Level of Local Government Owned Enterprises (BUMD) toward Papua Regional Income
}

\author{
Yohanis Rante, Westim Ratang, B. Elita Bharanti \\ Universitas Cenderawasih, Indonesia \\ Westim_ratang@yahoo.co.id
}

\begin{abstract}
In the effort to carry out the principal functions and duties for the population in Papua, Papua provincial government set up several enterprises (BUMD) purposed to provide services to the public. BUMD is also expected to give contribution on regional income. The objectives of this research are: (1) Determining the health level of Local Government Owned Enterprises in Water Supply Company in Jayapura and Nabire from the financial aspect, (2) the health level of Local Government Owned Enterprises in Water Supply Company in Jayapura from the operational aspect, (3) the health level of Local Government Owned Enterprises in Water Supply Company in Jayapura and Nabire from the administration aspect. The method used in this research is survey research method toward BUMD by distributing questionnaires in several enterprises. The analytical tool used is the analysis on the health level of Water Supply Company on the financial, operational and administration aspects. Jayapura Water Supply Company health level in terms of financial aspects, operations and administration in 2011 to 2013 showed a reduction, but it was still sufficient indication. The total value of these three aspects has decreased in the last two years, 60.49 in 2011, decrease to 59.22 in 2012 and 54.59 by the end of 2013 . However, this reduction was still at fairly healthcategory. Nabire Water Supply Company health level based on the financial aspect shows that from 2010 to 2013, the financial performance of Nabire Water Supply Company was experiencing unhealthy condition. Service aspect of the rate of complaints solving in 2010 to 2013 was always above $100 \%$, it means that Nabire Water Supply Company have solved the problem of water services and other complaints that come from customers or not customer. The next indicator is water quality was $0 \%$ from 2010 to 2013 . It means that they have not been able to serve the customers with the drinking water quality as provided in Ministry of Health Regulationnumber 492/MENKES/PER/IV/ 2010.
\end{abstract}

Keywords: Local government owned enterprises (BUMD), effectiveness, contributions, regional income

\section{Introduction}

Special Autonomy for Papua Province is intended to bring about justice, upholding the rule of law, respect human rights, accelerate economic development, and improve the welfare and progress of Papua people, in order to create equality and balance as the progress of other provinces. This legislation puts indigenous people of Papua and Papua population generally as the main subject. The existence of the government, both provincial and district/city governments, as well as the institutionare directed to provide the best service to the indigenous people of Papua and the empowerment of the people in order to increase social welfare, so that their lives of Papuan indigenous people can be aligned with the rest of the population in Indonesia. Regional autonomy era and globalization requires local governments to be a spearhead of economic development activities (BPPSPAM, 2014). Creativity and responsive movement of local government are needed in order to capture all of the opportunities and challenges from the environment that exist for the sake of regional economic growth (Rachman, 2007). In accordance with the vision and mission of the Provincial Government of Papua, Vision: "Papua Risen, independent and welfare" and Mission: (1) Creating security, peace and comfortable atmospheres for the whole Papua society in the sovereignty of Republic of Indonesia; (2) Achieving good, clean and charismatic Governance as well as the strengthening of the Special Autonomy; (3) Realizinghealthy,achievement and noble Papua Human Resources; (4) Development and Improvement of Economic with Local Potential based; (5) Acceleration of Infrastructure Development and Regional and Inter-Regional Connectivitieswith Sustainable Developmentprinciple priority (BPPSPAM, 2014). In the effort to carry out the principal functions and duties for the population in Papua, Papua provincial government set up several enterprises (BUMD) purposed to provide services to the public, BUMD is also 
expected to give contribution on regional income. In the effort to carry out the principal functions and duties for the population in Papua, Papua provincial government set up several enterprises (BUMD) purposed to provide services to the public, itis also expected to give contribution on regional income. The two roles of BUMD often cause problems in their implementation. When BUMD carry out a social function, the function as a contributor to the incomewill is less than optimal. On the other hand if it functions as a backstop source of local income is increased, itis feared social function of BUMD will less optimal (Peraturan Menteri Dalam Negeri Nomor 3 Tahun, 1998).

\section{Literature Review}

Financial Performance Ananlysis of Water Supply Company: The analytical instrument used to determine the performance of Jayapura and Nabire Water Supply Company both from the financial and operational aspects, as well as the administration aspect are based on the Ministry of Home Affairs Number 47 /1999 on Guidelines for Assessment of Regional Water Supply Company Performance (Fahmi, 2011):

a. Financial aspect looks at the ten indicators, they are:

- Profit ratio on earning assets

- Profit ratio on sales

- Current assets ratio on current debt

- Long-term debt ratioon equity

- Total assets ratio on total debt

- Operatingcost ratio on operating income

- Operating income before depreciation charges ratioon principal and interest maturity

- Productive assets ratio onwater sale

- Period ofdebt collection

- Billing effectiveness

b. Operational aspect looks at the ten indicators, they are:

- Scope of services

- Water Quality Distribution

- Water Continuity

- Production Installation Utilization Productivity

- Water Loss level

- Water Meter calibration

- New Connection Speed

- Ability of complaints handling average per month

- Easy Service

- The ratio of employees per 1,000 customers

c. Administrationaspect looks at the ten indicators, they are:

- Long-Term Plan (Corporate Plan)

- Organization and Duties Plan

- Standard Operating Procedures

- As Built Drawing

- Guidelines on Employee Performance Appraisal

- Work and Budget Plan (CBP)

- Conduct Internal Reports

- Conduct External Reports

- Independent Report Opinion 


\section{Methodology}

Financial Performance Analysis of Water Supply Company: The analytical instrument used to determine the performance of Jayapura and Nabire Water Supply Company both from the financial and operational aspects, as well as the administration aspect are based on the Ministry of Home Affairs Number 47 /1999 on Guidelines for Assessment of Regional Water Supply Company Performance. In order to determine the performance assessment of each aspect, the following formula is used (Munawir, 2007).
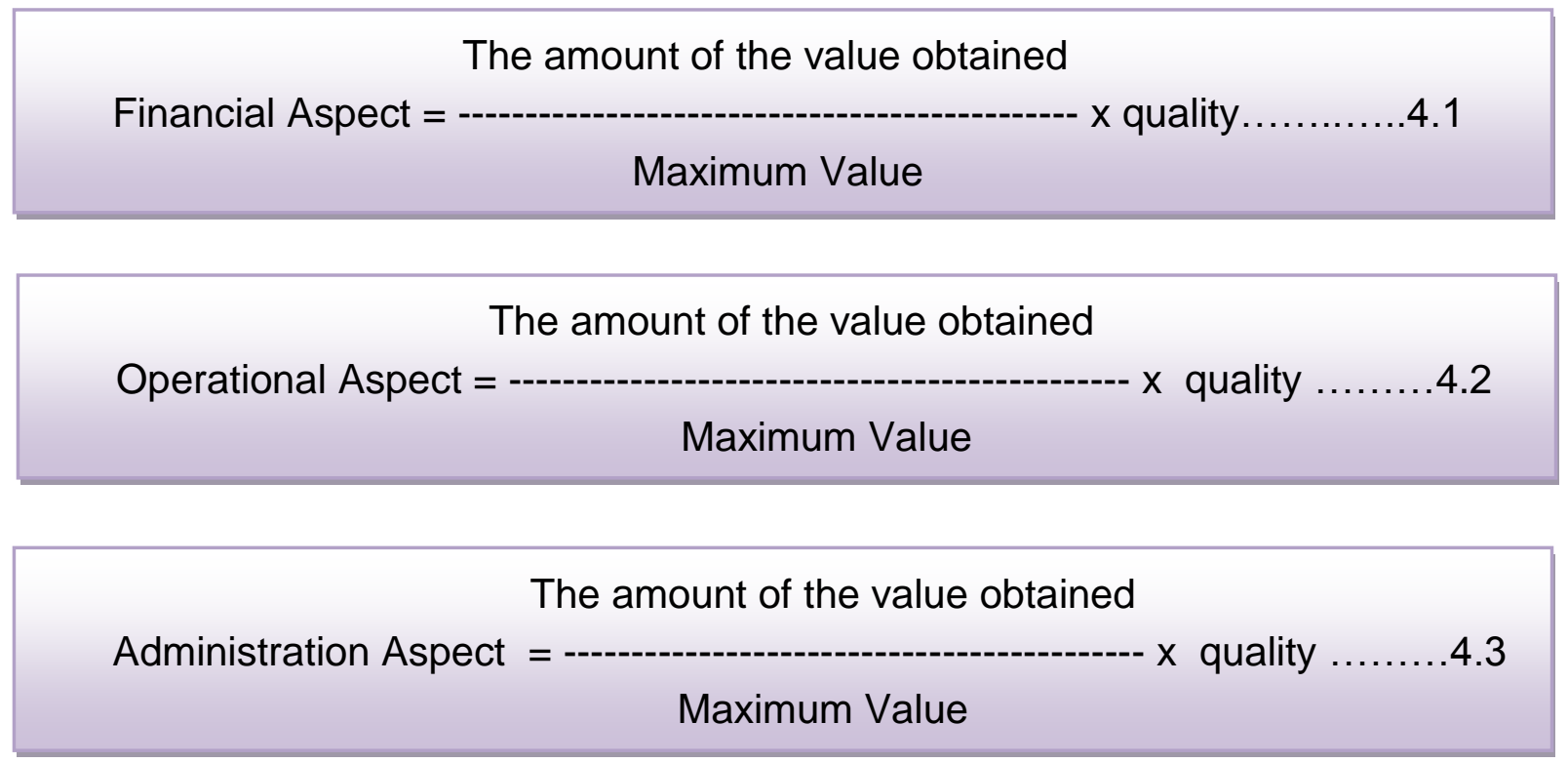

Helath Level: In order to know the company's development until 2004, it can be seen from the reports that have been examined/audited by Public Accountant, so the development of Jayapura Water Supply Company restricted from several aspects as follows, (Indriantoro \& Supomo, 2002).

- Financial Aspects.

- Technical and Operational Aspects.

- Administrative Aspects.

- Human Resources Aspects

Table 1: Analysis of Jayapura Water Supply Company Health Level

\begin{tabular}{llll}
\hline Aspect & $\mathbf{2 0 1 1}$ (Audit) & $\mathbf{2 0 1 2}$ (Audit) & $\mathbf{2 0 1 3}$ (Audit) \\
\hline Financial & 29,25 & 29,25 & 22,50 \\
Operational & 19,57 & 18,72 & 20,43 \\
Administration & 11,67 & 11,25 & 11,67 \\
Total Value & 60,49 & 59,22 & 54,59 \\
Rating & Good & Fair & Fair \\
\hline
\end{tabular}

Source: Data treated in 2014

\section{Finding and Discussion}

Health Level: Financial aspect looks at the ten indicators, they are Profit ratio on earning assets, Profit ratio on sales, Current assets ratio on current debt, Long-term debt ratio on equity, Total assets ratio on total debt, Operating cost ratio on operating income, Operating income before depreciation charges ratio on principal and interest maturity, Productive assets ratio on water sale, Period of debt collection, and Billing effectiveness. Category table ofperformance based on financial aspect below shows that from 2010 to 2013 
Nabire water supply company financial performance experiencing unhealthy condition. Profitability ratios consisting of ROE was negative and it means that water supply company ability to generate profits of capital is very low. Operating ratio shows a decrease from the value 022 in 2010 decreased to 1.6 in 2011 and increased to 1.8 in 2012 and 2013. The liquidity ratio is described by the cash ratio and billing effectiveness. Analysis shows that the cash ratio of Water Supply Companyexperienced a significant decrease from $45.30 \%$ in 2010 to $18 \%$ and $18.5 \%$ in 2011 and 2012 and then increased to $48.10 \%$ in 2013. The effectiveness of billing increased from $62.20 \%$ in 2010 , to $75 \%$ in $2011,79.3 \%$ in 2012 and decreased to $71.5 \%$. The solvency ratio shows the value of $3.8710 \%$ in 2011 , decreased by $2386.5 \%$ in 2012 but increased by $5881 \%$ in 2013 . The indicators used to describe service aspectare scope of services, customer growth, the level of complaints resolution, the water quality of the customer and the replacement of water meters. Service coverage has decreased significantly from $20 \%$ in 2010, $18 \%$ in 2011 and 14\% in 2012. The growth of customers has decreased from 2010 to 2011 , from $-6 \%$ to $-10 \%$ and increased $1 \%$ in 2012 and 2013 . The level of the complaint resolution in 2010 until 2013 always above 100\%. It means that NabireWater Supply Serviceshave solved the problem of water services and other complaints that come from customers or not customers. The next indicator of water quality customers shows $0 \%$ from 2010 to 2013, which means that the company have not been able to serve the customers with the quality of drinking water as provided for in Regulation of the Minister of Health 492/Meknes/Per/IV/2010. In the operationalaspect, there are five assessment indicators include production efficiency, the rate of water loss, service hours per day, the pressure of customer connections and replacement of water meters. Production efficiency in 2010 shows a value of $91 \%$, decreased to $89 \%$ in 2011 and $82.3 \%$ in 2012 . The rate of water loss which is an indicator that measures the extent to company management is able to control the sale of its products, drinking water, through the piping distribution system shows decrease which is quite significant. Operational hours of service per day explain that company is able to retain water drainage services to customers' shows a stable value is in position 2 and 3 since 2010 to 2013.

Customerspressure lines and replacement of water meters have a value that is not much different in the years of this research. Pressure connection that measures the company to which customers are able to maintain its service with drinking water qualification which should $3 \mathrm{~K}$ qualify achievements and results show that $40 \%$ of the value of 3 since 2010 until 2013. Replacement of water meters that describes the replacement meter of water supply company management or meter calibrating according to the regulations so that customers secure accuracy meter also shows poor grades in figure 1 and consistent in 2011 through 2013. The three indicators used in the assessment of human resources aspect, ratio of the employees/100 plg, employee training ratio divided by improving the competence and training costs for personnel costs. The ratio that measures the efficiency of Nabire water supply Company'semployee toward the customer indicates the value of this ratio decreased in late 2012 and 2013. The ratio of employee training/improving the competence that measure the level of employee competence shows a significant decrease from 2011 to 2012 and 2013 and is at a value of 1 . Cost of training employee toward the employee's cost explain the company's management that have appreciation in seeking employees to be competent and the results shows that from 2010 to 2013 there was no significant increase and better efforts to increase the employee of Nabire water supply company. Total performance of Nabire Water Supply Company in 2010 until 2013 in the range of 1.5 - 2, which means it is in the category of pain. The end of 2010 shows the value of 2.07 and then decreased in 2011 to 1.82 and slightly increase to 1.83 at the end of 2012 and 1.86 at the end of 2013.

\section{Conclusion}

- The health level of Jayapura Water Supply Company from the aspect of financial, operational and administration. In 2011 to 2013 shows a decrease, but it is still in sufficient indication. The total 1 value of these three aspects has decreased in the last two years, 60.49 in 2011, decrease to 59.22 in 2012 and 54.59 by the end of 2013 . This decline is still at fairly health category.

- The health level of Nabire Water Supply Company from the financial aspect shows that from 2010 to 2013, the financial performance experiencing unhealthy condition. Aspects of service of complaints resolve rate in 2010 until 2013 was always above 100\%. It means that Nabire Water Supply Company have solved the problem of water services and other complaints that come from customers or not customers. The next indicator of water quality shows 0\% from 2010 to 2013, which means 
that the Water Supply Company has not been able to serve its customers with the quality of drinking water as provided for in Regulation of the Minister of Health 492/Menkes/Per/IV/2010.

\section{References}

BPPSPAM. (2014). PDAM Performance Reports Year 2013 Region IV Papua. http://www.bppspam.com/index.php?option=com_docman\&Itemid=108

BPPSPAM. (2014). PDAM Performance Reports Year 2012 Region IV Papua. http://www.bppspam.com/index.php?option=com_docman\&Itemid=108.

BPPSPAM. (2014). Investment Opportunity of Water Supply Sectors in Indonesia.http://www.bppspam.com/index.php?option=com_docman\&Itemid=108

Fahmi, I. (2011). Analysis Financial. Alfabeta. CV. Bandung.

Indriantoro, N. \& Supomo, B. (2002). Research Methodology for Business and Management Accounting. Edition I. BPFE.Yogyakarta.

Munawir, S. (2007). Analysis Financial. Edition IV. Edition 14. Yogyakarta: Liberty.

Minister Regulation No. 3 of 1998 on Legal Forms enterprise BUMD

Rachman, A. (2007). Analysis Contributions of Local Taxes and Profit ROE against Local Revenue: A Case Study in County Government Boyolali. Jogjakarta. 